\title{
Yield and Water Use of Eggplant (Solanum melongena L.) Under Different Irrigation Regimes and Fertilizers
}

Farklı Sulama Rejimleri ve Gübreler Altında Patlıcanın (Solanum melongena L.) Verim ve Su Kullanımı

\author{
Mahmud ALí ${ }^{1}$, Cafer GENÇOĞLAN ${ }^{2}$, Serpil GENÇOĞLAN ${ }^{3}$, Ali Beyhan UÇAK ${ }^{4}$
}

\begin{abstract}
This study was conducted in Bandırma (Balıkesir, Turkey) during the growing season of the plant in 2017 and 2018 to determine the effect of four levels of irrigation water and three kinds of fertilizer on yield and water use of field-grown eggplant (solanum melongena). Treatments included four irrigation regimes, which were $100 \%$ ( $\mathrm{I}_{100}$, control), $80 \%\left(\mathrm{I}_{80}\right), 60 \%\left(\mathrm{I}_{60}\right)$, and $40 \%$ ( $\left.\mathrm{I}_{40}\right)$ of evaporation from Class A Pan and three different fertilizers, which were chemical fertilizer CHF; N, P, K (20-20-20+15 SO 3$)$ added as $40 \mathrm{~kg} \mathrm{da}^{-1}$ organic fertilizer (OF) added as $2000 \mathrm{~kg} \mathrm{da}^{-1}$ and developed organic fertilizer (DOF) added as $2000 \mathrm{~kg} \mathrm{da}^{-1}$. Total irrigation water of $305 \mathrm{~mm}$ and $360 \mathrm{~mm}$ were applied to $\mathrm{I}_{100}$ irrigation treatment, in which water use was determined as $447 \mathrm{~mm}$ and $436 \mathrm{~mm}$, respectively. In both experiment years, the effect of irrigation level on fruit yield was found to be significant statistically $(\mathrm{p}<0.05)$ but the effect of fertilizers treatments and irrigation $\mathrm{x}$ fertilizer interaction was insignificant $(\mathrm{p}>0.05)$. The highest yield with 3681 and $4515 \mathrm{~kg} \mathrm{da}^{-1}$ was harvested from $\mathrm{I}_{100}$ irrigation treatment, and the lowest yield with 3021 and $2792 \mathrm{~kg} \mathrm{da}^{-1}$ from I 40 irrigation treatment, respectively. As for fertilizer, the highest yield with 3462 and $3878 \mathrm{~kg} \mathrm{da}^{-1}$ was harvested from DOF, while the lowest yield with 3258 and 3629 $\mathrm{kg} \mathrm{da}^{-1}$ from OF, respectively. Water use efficiency (WUE) ranged from 8.26 to $12.54 \mathrm{~kg} \mathrm{~mm}^{-1}$ and irrigation water use efficiency (IWUE) from 11.9 to $25.68 \mathrm{~kg} \mathrm{~mm}^{-1}$ in the experimental years. Thus, in irrigation programming, the Kcp3: 0.80 plant-pan coefficient and in fertilizer application, DOF is recommended for fieldgrown eggplant.
\end{abstract}

Keywords: Chemical fertilizer, Drip irrigation, Eggplant, Organic fertilizer, Water-yield relationship

\footnotetext{
1*Sorumlu Yazar/Corresponding Author: Mahmud ALİ, Department of Bioengineering and Sciences, Institute of Science, University of Kahramanmaras Sutcu Imam, Turkey. E-mail: mahmoudali1968@hotmail.com (iD OrcID: 0000-0002-9000-8385

${ }^{2}$ Cafer Gençoğlan, Department of Biosystem, Faculty of Agriculture, University of Kahramanmaras Sutcu Imam, Kahramanmaraş, Turkey, E-mail: gencoglan@ksu.edu.tr (D) OrcID: 0000-0002-4559-4354.

${ }^{3}$ Serpil Gençoğlan, Adress, Department of Biosystem, Faculty of Agriculture, University of Kahramanmaras Sutcu Imam, Kahramanmaraş, Turkey. E-mail: sgencoglan@ksu.edu.tr (D) OrcID: 0000-0002-7390-8365.

${ }^{4}$ Ali beyhan UÇAK, Department of Biosystem, Faculty of Agriculture, University of Siirt, Siirt, Turkey. E-mail: alibeyhanucak@gmail.com (iD) OrcID: 00000003-4344-2848

Atıf/Citation: ALI M., GENÇOĞLAN C., GENÇOĞLAN S., UÇAK A.B., Yield and Water Use of Eggplants (Solanum melongena L.) Under Different Irrigation Regimes and Fertilizers. Tekirdă̆ Ziraat Fakültesi Dergisi, 18 (3), 533-544.

CBu çalışma Tekirdağ Namık Kemal Üniversitesi tarafından Creative Commons Lisansı (https://creativecommons.org/licenses/by-nc/4.0/) kapsamında yayınlanmıştır. Tekirdağ 2021
} 


\section{$\ddot{\mathbf{O} z}$}

$\mathrm{Bu}$ çalışmanın amacı, üç farklı gübre ve dört farklı düzeydeki sulama suyu miktarlarının patlıcan bitkisinin verimine, kalitesine ve su-verim ilişkisine etkisini belirlemektir. Araştırma, Bandırma koşullarında 2017 ve 2018 yıllarında patlıcan bitkisinin yetişme sezonu boyunca yürütülmüştür. Çalışmada; 3 farklı gübre ve 4 farklı sulama düzeyi kullanılmıştır. Gübre konuları, kimyasal gübre CHF; N, P, K (20-20-20+15 SO3) $40 \mathrm{~kg} \mathrm{da}{ }^{-1}$ olarak eklendi, organik gübre (OF) $2000 \mathrm{~kg} \mathrm{da}^{-1}$ olarak eklendi ve gelişmiş organik gübre (DOF) $2000 \mathrm{~kg} \mathrm{da}^{-1}$ olarak eklenmiştir. Dört farklı sulama konusu ise A Sınıfı Buharlaşma Kabı'ndan oluşan buharlaşmanın \% 100 ( $\mathrm{I}_{100}$, kontrol), \%80 ( $\left.\mathrm{I}_{80}\right), \% 60$ ( $\left.\mathrm{I}_{60}\right)$ ve \%40 ( $\left.\mathrm{I}_{40}\right)$ 'nın verilmesi şeklinde oluşturulmuştur. Sulama suyu miktarı 2017 ve 2018 y1llarında sırasıyla 122 - $305 \mathrm{~mm}$ ile ve 147 - $360 \mathrm{~mm}$ ve bitki su tüketimi araştırma 2017 ve 2018 yılları için sırasıyla 264 - $447 \mathrm{~mm}$ ve 217 - $436 \mathrm{~mm} 533$ la değişmeştir. Araştırma sonucuna göre patlıcanın verim değerleri üzerine sulama suyu konusunun etk... …..iksel olarak önemli bulunmuştur $(\mathrm{P}<0.05)$. Gübre uygulaması ve sulama konusu $\mathrm{x}$ gübre interaksiyonu etkisinin önemsiz olduğu belirlenmiştir. Araştırmada en yüksek meyve verimi, 2017 ve 2018 yıllarında sirasıyla $3681 \mathrm{~kg} \mathrm{da}^{-1}$ ve $4515 \mathrm{~kg} \mathrm{da}^{-1}$ ile I $\mathrm{I}_{100}$ sulama konusundan, en düşük meyve verimi ise sırasıyla $3021 \mathrm{~kg} \mathrm{da}^{-1}$ ve $2792 \mathrm{~kg} \mathrm{da}^{-1}$ ile $\mathrm{I}_{40}$ sulama konusunda elde edilmiştir. Gübre uygulamalarında her sulama konusu için en yüksek verim 3462 ve $3878 \mathrm{~kg} \mathrm{da}^{-1}$ DOF uygulamasında ve en düşük verim ise 3258 ve $3629 \mathrm{~kg} \mathrm{da}^{-1}$ OF gübre uygulamasında elde edilmiştir. Deneme yıllarında su kullanım randamanı (WUE) 8.26 ile $12.54 \mathrm{~kg} \mathrm{~mm}^{-1}$, sulama suyu kullanım randamanı (IWUE) ise 11.9 ile $25.68 \mathrm{~kg} \mathrm{~mm}^{-1}$ arasında değişmiştir. $\mathrm{Bu}$ nedenle sulama programlamasında Kcp3: 0.80 bitki katsayısı ve DOF gübre uygulamasında yetiştirilen patlıcan için önerebiliriz.

Anahtar Kelimeler: Damla sulama, Kimyasal gübre, Organik gübre, Patlıcan, Su-verim ilişkisi. 


\section{Introduction}

In our century, the world's population has been constantly increasing, agricultural lands and clean water resources have been gradually decreasing, access to food and water will be more difficult for countries, and agriculture will continue to be the most strategic sector of the two thousand years. In addition to providing basic nutrients by agriculture, the production of fresh fruits and vegetables, in general, is of vital importance in terms of supplying healthy nutrition. With the limited water resources availability in the Middle East and the rapid and unplanned consumption of water in industry and agriculture in recent years, these existing resources are threatened in terms of quality and quantity. Therefore, it is necessary to know the amount of water consumed by cultivated crops for water resources sustainability. In this context, it is necessary to determine the water consumption for eggplant and other vegetables that have a high economic and healthy value. Application of deficit irrigation in crop production is an approach to save water in areas of water shortage and longer drought during the production period to maximize water productivity. Deficit irrigation saves a large amount of irrigation water and increases water use efficiency (Kirda, 2002). Kirnak et al. (2002) results show that eggplant can be drip-irrigated with 8-day irrigation intervals at $80 \%$ of Class A Pan evaporation without decreasing yield but with significant water savings and improve fruit quality compared to control. Diaz-Perez (2015) concluded that eggplant tolerate moderate water stress, and plants irrigated at $67 \%$ ETc produced fruit yields similar to those of plants irrigated at $100 \%$ ETc. So, there is a possibility to save water by decreasing current irrigation rates without negatively affecting the fruit yields. Demirel et al. (2014) reported that yield reductions of $18.16 \%$ and $27.13 \%$ were observed under low and moderate water stress. It was observed that the highest average eggplant fruit weight was in treatment exposed to full irrigation amount (100\%). Kirnak et al. (2001) studied the effects of irrigation regime on eggplant and observed that water stress led to a significant decrease in chlorophyll content, leaf water content and vegetative growth, and fruit yield and quality. Chaves et al. (2003) concluded that crop vegetative growth and yield decrease with increasing water stress. Lovelli et al. (2007) illustrated that eggplant fresh yield ranged from $48.2 \mathrm{t}$ ha-1 in $\mathrm{kcp}: 100 \%$, to $11.4 \mathrm{t} \mathrm{ha}^{-1}$ in $\mathrm{kcp}: 25 \%$. Aujla et al. (2007) determined fresh eggplant yields varying from 43.1 to $103.1 \mathrm{t} \mathrm{ha}^{-1}$ in India. Mohawesh and Karajeh (2014) reported that water deficit reduced the growth of eggplant components. The common cause of the reduced vegetative growth of vegetables under water deficit conditions has been thought to be accelerated leaf senescence, as reported by Kirnak et al. (2002). El-Miniawy (2015) concluded that irrigation using different irrigation regimes significantly affected the eggplant vegetative growth parameters, i.e., plant height, number of branches and leaves, leaf area, and fresh and dry weights of leaves. Among irrigation regimes, the highest plant vegetative growth characters were observed in irrigation treatment after depletion of $70-75 \%$ of available soil water. Provided $509 \mathrm{~mm}$ of irrigation water led eggplant to intercept $35 \%$ of the active light radiation. Therefore, applying irrigation water of $509 \mathrm{~mm}$ in semi-arid regions for eggplant production seems to be a more appropriate level for getting a higher yield (Yıldırım, 2015). Ertek et al. (2006) reported irrigation water values varied between $372 \mathrm{~mm}$ and $689 \mathrm{~mm}$ for furrow irrigated eggplant in Turkey. Aujla et al. (2007) concluded that irrigation water amounts changed between 413 and $826 \mathrm{~mm}$ for different treatments for drip-irrigated eggplant in India. The seasonal average ET of drip-irrigated eggplant changed between 905 and $1375 \mathrm{~mm}$ by Kirnak et al. (2002) in the Harran plain of Turkey and $719 \mathrm{~mm}$ and $1196 \mathrm{~mm}$ by Aujla et al. (2007) in India and 147 and $469 \mathrm{~mm}$ by Lovelli et al. (2007) in Southern Italy and 150 and $590 \mathrm{~mm}$ by Karam et al. (2011) in the central Bekaa Valley of Lebanon, and furrow irrigated between $420 \mathrm{~mm}$ and $689 \mathrm{~mm}$ by Ertek et al. (2006) in the Mediterranean region of Turkey. Karam et al. (2011) founded the highest WUE value in the deficit irrigation treatment as $5.6 \mathrm{~kg} \mathrm{~mm}-1$ in Lebanon. Eggplant WUE increased under water stress conditions (Kurnak et al. 2002). Amiri et al. (2012) demonstrated that WUE for eggplant varied from 4.36 to $11.6 \mathrm{~kg} \mathrm{~mm}-1$; the highest amount of WUE was recorded in plants irrigated every 6 days and received $120 \mathrm{~kg}$ nitrogen per hectare. Supplying plants with an optimum level of all plant nutrients are primary for the production of top-quality fruit and good production levels (Hochmuth et al., 1993). Nitrogen is one of the main elements for plant growth and development which plays an important role in plant nutrition and thus, it is one of the factors that limit plant yield and growth in many areas. Nitrogenous fertilizers often have mobility in soils, and they can contaminate soils and groundwater. And therefore, management of $\mathrm{N}$ rate, type, application time is very important (DePascale et al., 2006). Rosati et al. (2001) observed that by increasing nitrogen, leaf area index, light interception, and dry matter of eggplant increased. Aminifard et al. (2010) studied the effect of four rates of nitrogen fertilizer on growth and yield of eggplant and found that plant height, branch numbers, leaf chlorophyll content, flower number, fruit weight, and fruit yield 
were affected by nitrogen rate. El-Miniawy (2015) concluded that irrigation of eggplants after the depletion of $70-75 \%$ of the available soil water plus the application of 100 or $150 \mathrm{~kg} \mathrm{~K}_{2} \mathrm{O}$ feddan ${ }^{-1}$ resulted in the highest vegetative growth and yield of eggplant. De et al. (1996) concluded that increasing K application for eggplant increased vegetative growth parameters, i.e., plant height and crop growth rate as well as dry matter accumulation. Inorganic fertilizers are known as their high cost and their bad environmental effects if managed poorly (Morris et al., 2007). In a certain experiment, the researchers found that using the organic application had the potential to increase the growth and chemical composition of two cultivars of safflower and therefore, it may be a good alternative to chemical fertilizers (Naderi and Bijanzadeh, 2014). Louisa and Taguiling (2016) resulted that compost motivate plant growth parameters such as height, number of leaves, fresh weight of plant biomass, and yield of eggplant (Solanum melongena). Organic fertilizer was obtained from microbial composting of organic agricultural and domestic wastes. It was found that organic fertilizer application for eggplant it will be superior to chemical fertilizers in terms of vegetative growth, fruit yield, and quality attributes. Organic fertilizer slightly decreased the vegetative period and improved the yield components and total marketable fruit yield. Organic fertilizer could be recommended as a complete alternative for chemical fertilizers in eggplant production (Dinh Hoa, 2008). Mechanochemical activation can be defined as a process being able to induce structural disorder through intensive grinding. In certain conditions, it may increase the chemical reactivity of the processed material (Tole et al., 2019). Therefore, the objective of this study was to determine the effects of different irrigation levels on the yield and quality parameters of the eggplant under field conditions using Class A Pan evaporation calculations and different plant-pan coefficients and to study the effect of organic and inorganic fertilizer on growth and yield of eggplant (Solanum melongena).

\section{Materials and Methods}

The experiment was carried out in Bandirma in a field located at $40^{\circ} 16^{\prime} 44.4252^{\prime \prime}$ North and $28^{\circ} 4^{\prime} 18.9552$ " Eastern latitudes and longitudes and its altitude is $41 \mathrm{~m}$. The prevailing climate in Bandırma is the Mediterranean Sea and the Black Sea. Besides, because it is located in the transition area of the terrestrial climate of the Balkans, the average lowest and the highest temperature of 52 -years are $5.3{ }^{\circ} \mathrm{C}$ and $23.9^{\circ} \mathrm{C}$ with an annual mean of $14{ }^{\circ} \mathrm{C}$. Rainfall, wind speed, and relative humidity are $14{ }^{\circ} \mathrm{C}, 703.3 \mathrm{~mm}, 15 \mathrm{~km} \mathrm{~h}^{-1}$, and $73 \%$, respectively (Anonymous, 2017).

Disturbed and undisturbed soil samples belong to the experiment area were taken from 0-30, 30-60, and 60$90 \mathrm{~cm}$ soil layers and then physical and chemical analyses were performed on these samples (Table 1). The $\mathrm{pH}$ of soil ranged from 8 to 8.1 , EC 0.76 to $0.84 \mathrm{dS} \mathrm{m}^{-1}$, organic matter $\% 0.68$ to $\% 1.2$, total nitrogen $\% 0.090$ to $\% 0.097$, phosphorus 1.44 to $1.69 \mathrm{~kg} \mathrm{da}^{-1}$, potassium 59.8 to $83.8 \mathrm{~kg} \mathrm{da}^{-1}$, and volume weight (As) 1.28 to $1.31 \mathrm{~g}$ $\mathrm{cm}^{-3}$. The soil texture in the first layer $(0-30 \mathrm{~cm})$ is sandy clay; in the second layer $(30-60 \mathrm{~cm})$ sandy silt clay; the third layer $(60-90 \mathrm{~cm})$ silty.

In experiment there is 36 parcels, parcel dimensions were $8 \times 4.2 \mathrm{~m}=33.6 \mathrm{~m}^{2}$ The total area of parcels is $1209.6 \mathrm{~m}^{2}$. The distance between the rows in each parcel $70 \mathrm{~cm}$, the distance between plants in the row is $40 \mathrm{~cm}$. In every row There are 20 plants the total plants in each parcel is 120 plants in. for avoiding interaction between parcels 2 meters' buffer zone was created, so the total area of the experiment was $2380.8 \mathrm{~m}^{2}$. Total number of eggplant seedlings transplanted in the experiment area is 4320 seedling.

Irrigation water is pumped from the deep well near the experiment plot into a pool. Samples were collected from the irrigation water and then analyzed. The class of irrigation water is determined as C3S1 (Table 2), so this water is suitable for irrigation of eggplant as it was reported by Ünlükara et al. (2010).

In the experiment, eggplant cv. Karnaz variety was used as experiment material.

Table 1. Some physical and chemical properties of soil at the experiment area

\begin{tabular}{|c|c|c|c|c|c|c|c|c|c|c|c|c|c|}
\hline $\begin{array}{c}\text { Profile } \\
(\mathrm{cm})\end{array}$ & $\mathrm{PH}$ & $\begin{array}{c}\mathrm{EC} \\
\mathrm{dS} \mathrm{cm}^{-1}\end{array}$ & $\begin{array}{c}\mathrm{OM} \\
\%\end{array}$ & $\begin{array}{c}\text { Totatal } \\
\text { N\% }\end{array}$ & $\begin{array}{l}\mathrm{P}_{2} \mathrm{O}_{5} \\
\mathrm{Kg} \mathrm{da}^{-1}\end{array}$ & $\underset{\mathrm{Kg} \mathrm{da}^{-1}}{\mathrm{~K}_{2} \mathrm{O}}$ & $\begin{array}{c}\text { As } \\
\left(\mathrm{g} \mathrm{m}^{-3}\right)\end{array}$ & $\begin{array}{l}\text { WP } \\
\left(P_{w}\right)\end{array}$ & $\begin{array}{c}\mathrm{FC} \\
(\mathrm{Pw})\end{array}$ & $\begin{array}{c}\text { Sand } \\
\% \\
\end{array}$ & $\begin{array}{c}\text { Silt } \\
\% \\
\end{array}$ & $\begin{array}{c}\text { Clay } \\
\% \\
\end{array}$ & Texture \\
\hline $0-30$ & 8.0 & 0.76 & 1.20 & 0.094 & 1.69 & 83.8 & 1.28 & 20.4 & 38.95 & 30.6 & 12.1 & 57.3 & $\begin{array}{l}\text { Sandy } \\
\text { Clay }\end{array}$ \\
\hline $30-60$ & 8.1 & 0.82 & 0.97 & 0.090 & 1.44 & 67.9 & 1.31 & 19.8 & 38.72 & 30.7 & 16.0 & 53.3 & $\begin{array}{l}\text { Sandy } \\
\text { Silt clay }\end{array}$ \\
\hline $60-90$ & 8.1 & 0.84 & 0.68 & 0.097 & $<0.7$ & 59.8 & 1.28 & 20.3 & 39.15 & 28.6 & 16.0 & 55.4 & silty \\
\hline
\end{tabular}

As; volume weight of soil, FC; field capacity, OM; organic matter, WP; wilting point. 


\begin{tabular}{ccccccccccccccc}
\hline \multicolumn{10}{c}{ Table 2. Chemical properties of water used in irrigation } \\
\hline
\end{tabular}

SAR; sodium absorption rate, RSC; residual sodium carbonate, PS; potential salinity.

In the study, treatments were selected to the determinate effect of four different irrigation levels and three different fertilizers on fruit yield, some vegetative growth indicators, and water yield relationship of eggplant. Irrigation and fertilizer treatment was planned in the main and sub-parcels, respectively, and formed in a split plots randomized block design with three replicates. Irrigation treatments were established with $100 \%\left(\mathrm{I}_{100}\right.$, control), $80 \%$ ( $\left.\mathrm{I}_{80}\right), 60 \%\left(\mathrm{I}_{60}\right)$, and $40 \%\left(\mathrm{I}_{40}\right)$ of the total amount of evaporated from Class A Pan when total evaporation was $40 \mathrm{~mm}$ or more. Fertilizer treatments were organic fertilizer (OF) with $2000 \mathrm{~kg} \mathrm{da}^{-1}$, developed organic fertilizer (DOF) with $2000 \mathrm{~kg} \mathrm{da}^{-1}$, and chemical fertilizer (CHF) with $40 \mathrm{~kg} \mathrm{da}^{-1}$, which was the control for fertilizers. CHF, which was called compound fertilizers, contains major elements of N, P, K (15-15-15 + 20 SO3). OF and DOF consists of $75 \%$ cow manure and $25 \%$ chicken manure, prepared in anaerobic fermentation method The difference between Normal Organic fertilizer (OF) and developed organic fertilizer (DOF) is that $20 \%$ of developed organic fertilizer prepared by a mechanical activation process using a high energy ball milling machine (Ibrahim et al., 2010). OF and DOF were granulated up to a grain size of 1 to $8 \mathrm{~mm}$ to make slowrelease organic fertilizers. In both organic fertilizers, OM content is $33 \%$, the humic + fulvic content is $18.4 \%$ and the $\mathrm{pH}$ is 7.4 (Table 3).

Table 3. Chemical properties of organic fertilizers ( $O F$ and $D O F$ )

\begin{tabular}{ccccccc}
\hline \multirow{2}{*}{$\mathrm{PH}$} & $\begin{array}{c}\text { OM. } \\
(\%)\end{array}$ & $\begin{array}{c}\text { Moisture } \\
(\%)\end{array}$ & $\begin{array}{c}\text { Humik+volvik } \\
(\%)\end{array}$ & $\begin{array}{c}\text { Total N } \\
(\%)\end{array}$ & $\begin{array}{c}\mathrm{P}_{2} \mathrm{O}_{5} \\
(\%)\end{array}$ & $\begin{array}{c}\mathrm{K}_{2} \mathrm{O} \\
(\%)\end{array}$ \\
\hline 7.4 & 32.9 & 10.7 & 18.4 & 1.88 & 2.04 & 1.2 \\
\hline
\end{tabular}

In both research years, the experimental area was tilled, plots were created, and fertilizers were applied, and then fertilizer was mixed into soil by hoeing machine. After that, the drip irrigation system was installed, eggplant seedlings were planted in the two research years on 02.06 .2017 and 22.05 .2018 according to the experiment plan, and also to establish seedlings, irrigation of $50 \mathrm{~mm}$ was applied to all experimental plots. Then, scheduled irrigations started based on the amount of evaporation from Class A Pan when the total evaporation amount was equal to or more than $40 \mathrm{~mm}$. The spacing between rows was $70 \mathrm{~cm}$, the spacing within rows was $40 \mathrm{~cm}$, and each parcel with 120 plants contained 6 rows, one of which has 20 plants. Plots size was $8 \mathrm{~m} \times 4.2 \mathrm{~m}$ $\left(33.6 \mathrm{~m}^{2}\right)$. The total number of the plots was 36 , the space between the plots was $2 \mathrm{~m}$, the total area of the experiment was $2380.8 \mathrm{~m}^{2}$. Doing every irrigation before 24 hours, soil samples from layers of $0-30,30-60$, and $60-90 \mathrm{~cm}$ were taken by spiral auger method to determine the moisture content in the soil profiles and dried at $105^{\circ} \mathrm{C}$ in the oven for 24 hours. Evapotranspiration (ET) was calculated with the equation (Eq. 1) (Garrity et al., 1982; James et al., 1982; Gençoğlan et al. 2006, Demirel et al., 2012):

$$
\mathrm{ET}=\mathrm{I}+\mathrm{P} \pm \mathrm{DSW}-\mathrm{Dp}-\mathrm{Rf}
$$

Where ET is the evapotranspiration $(\mathrm{mm})$, I the amount of irrigation water applied $(\mathrm{mm}), \mathrm{P}$ the precipitation $(\mathrm{mm})$, DSW the soil water content change $(\mathrm{mm})$ in the $60 \mathrm{~cm}$ soil profile (effective rooting depth of eggplant), Dp the deep percolation $(\mathrm{mm})$, and Rf the amount of runoff $(\mathrm{mm})$. Since the amount of irrigation water was controlled, the runoff was assumed to be zero. Monitoring soil water content in the plots revealed that deep percolation was negligible below $60 \mathrm{~cm}$ depth.

In the calculation of the amount of irrigation water, the method is given by Allen et al. (1998) was followed: Crop evapotranspiration is calculated directly using Equation 2.

$\mathrm{ETc}=\mathrm{K}_{\mathrm{cp}} \mathrm{E}_{\mathrm{pan}}$

Where ETc is the crop evapotranspiration ( $\mathrm{mm}$ ), $\mathrm{Kcp}$ is the crop-pan coefficient and $\mathrm{E}_{\mathrm{pan}}$ is pan evaporation $(\mathrm{mm})$. Four crop-pan coefficients, $\mathrm{Kcp} 1=0.40, \mathrm{Kcp} 2=0.60, \mathrm{Kcp} 3=0.80$ and $\mathrm{Kcp} 4=1.00$ were used to determine response of eggplant to different level of water. For this aim, a screened Class A Pan $(1210 \mathrm{~mm}$ in diameter and $250 \mathrm{~mm}$ depth and made of Galvanized metal with $0.8 \mathrm{~mm}$ thickness) was located on a wooden 
base next to the experimental field, surrounded by vegetation but no shadowing (Doorenbos and Pruitt, 1977). Daily evaporation was measured from Class A Pan at 09:00 using by hook gauge. The water level in the pan was kept between 150 - $200 \mathrm{~mm}$, whenever the water level in the pan dropped below $150 \mathrm{~mm}$; the pan was again filled with water up to $200 \mathrm{~mm}$. The daily pan evaporation was calculated by subtracting the hook gauge measurement values from the previous day to the next day. Daily pan evaporation was added and when cumulative pan evaporation was $40 \mathrm{~mm}$ and more, irrigations started. The amount of irrigation water was calculated from Equations 3 and 4.

$$
\begin{aligned}
& \mathrm{I}=\mathrm{ETc} \text { fw } \\
& \mathrm{V}=\mathrm{IA}
\end{aligned}
$$

Where $\mathrm{fw}$ is the wetting factor, $\mathrm{V}$ is the volume of irrigation water applied to irrigation plots (L), and $\mathrm{A}$ is the plot area $\left(\mathrm{m}^{2}\right)$. Eq. (5) was used in the determination of the wetting factor according to plant coverage (Ertek and Kanber, 2003).

$$
f w=\frac{a}{b}
$$

Where: (a); plant canopy diameter $(\mathrm{cm}),(\mathrm{b})$; row spacing $(\mathrm{cm})$.

Plant canopy diameter (a) was taken before every irrigation from the average of 5 plant diameter in each irrigation treatment. Water-use efficiency (WUE) and irrigation water-use efficiency (IWUE) values were calculated as fresh eggplant fruits yield divided by seasonal ET and total seasonal irrigation water applied, respectively (Tanner and Sinclair, 1983; Howell et al., 1990). Regression analysis was used to determine production functions for eggplant yield versus I and ET. Marketable eggplants were hand-harvested five times and weighed from August $9^{\text {th }}$ to October $5^{\text {th }}$ in the first season and from July $19^{\text {th }}$ to September $12^{\text {th }}$ in the second season. After the last fruit harvest, removing them from the soil with their roots and cleaned from the soil, all the plants in each parcel were weighed.

Analysis of variance was performed on yield and plant fresh weight, 5\% level of significant difference (LSD at $\mathrm{P}<0.05)$ was used in ANOVA to test the effect of irrigation and fertilizers treatments on different response variables (Steel and Torrie, 1980).

\section{Results and Discussion}

\subsection{Applied irrigation water (I) and evapotranspiration (ET)}

In two growing season, total pan evaporation was measured as 579 and $599 \mathrm{~mm}$, and precipitation were 143 and $86 \mathrm{~mm}$, and treatments were irrigated 12 and 13 times (Table 4). Total amounts of applied irrigation water changed between 122 and $305 \mathrm{~mm}$ in 2017, and between 147 and $360 \mathrm{~mm}$ in 2018 The differences in irrigation water between the two experiment years related to the differences in precipitation (Table 4). Evapotranspiration ranged from 264 to $447 \mathrm{~mm}$ in the first year and $217 \mathrm{~mm}$ to $436 \mathrm{~mm}$ in the second year (Table 4). The relations between irrigation I, evapotranspiration ET and yield were defined respectively as $\mathrm{Y}=3.6^{*} \mathrm{I}+2575, \mathrm{Y}=8.2 * \mathrm{I}+$ $1683, \mathrm{Y}=3.6 * \mathrm{ET}+2064, \mathrm{Y}=8.0003 * \mathrm{ET}+1144$. Significant linear relationships were obtained between the irrigation water $(\mathrm{I}, \mathrm{mm})$ and evapotranspiration $(\mathrm{ET}, \mathrm{mm})$ versus eggplant yield for irrigation treatments $(\mathrm{P}<$ 0.05) (Figure 1). It can be concluded that as the amount of irrigation water and ET value increased from $\mathrm{I}_{40}$ to I100, the yield of eggplant fruits increased, and also the seasonal evapotranspiration (ET) increased with the increasing amount of irrigation (I). Ertek et al. (2006) reported that the amount of irrigation water ranged from 372 to $689 \mathrm{~mm}$, while the average plant water consumption values vary between 420 and $689 \mathrm{~mm}$. Ayas (2017) concluded that irrigation water and evapotranspiration of eggplant ranged from 85 to $464 \mathrm{~mm} 170$ to $472 \mathrm{~mm}$. Şenyiğit et al. (2011) found the amount of the applied irrigation water and evapotranspiration (ET) ranged between 95.2 and $238.7 \mathrm{~mm}$, and from 93.1 to $466.3 \mathrm{~mm}$ in the greenhouse. Çolak et al. (2017) reported that the total amount of the applied irrigation water changed between $243 \mathrm{~mm}$ and $495 \mathrm{~mm}$ among the surface dripirrigated treatments and it varied from $228 \mathrm{~mm}$ to $446 \mathrm{~mm}$ in the subsurface drip plots. He found that evapotranspiration (ET) of eggplant was between 339 and $543 \mathrm{~mm}$ in surface drip system treatments and 306 and $495 \mathrm{~mm}$ in subsurface drip system treatments. Lovelli et al. (2007) found that eggplant evapotranspiration (ET) varied from 339 to $543 \mathrm{~mm}$ and from 306 to $495 \mathrm{~mm}$ in surface drip and from 306 to $495 \mathrm{~mm}$ in subsurface drip 
treatments, respectively. The results were obtained by Ayas (2017), Çolak et al. (2017), and Şenyiğit et al. (2011) are compatible with this research results. However, the results obtained by Ertek et al. (2006) are somewhat different due to different irrigation management and climatic conditions in the research area. About the effect of fertilizer on ET, no effect has been noticed, because the same amounts of water have been applied to all fertilizer treatments in every irrigation treatment depending on Class A Pan evaporation.

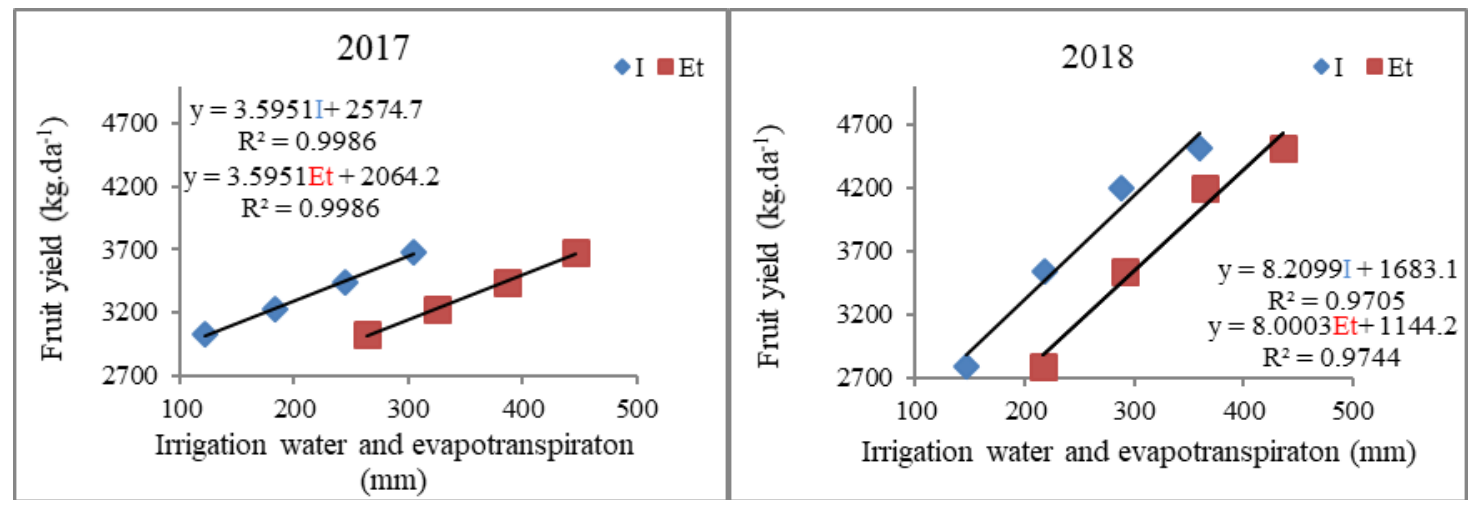

Figure 1. Yield and irrigation water and evapotranspiration relationship (2017-2018)

Table 4. Applied irrigation water amounts and calculated evapotranspiration in irrigation plots

\begin{tabular}{c|cccccc|cccccc}
\hline & \multicolumn{7}{|c|}{2017} & \multicolumn{7}{c}{2018} \\
\hline $\begin{array}{c}\text { Irr. } \\
\text { no. }\end{array}$ & $\begin{array}{c}\mathrm{I}_{40} \\
(\mathrm{~mm})\end{array}$ & $\begin{array}{c}\mathrm{I}_{60} \\
(\mathrm{~mm})\end{array}$ & $\begin{array}{c}\mathrm{I}_{80} \\
(\mathrm{~mm})\end{array}$ & $\begin{array}{c}\mathrm{I}_{100} \\
(\mathrm{~mm})\end{array}$ & $\begin{array}{c}\mathrm{P} \\
(\mathrm{mm})\end{array}$ & $\begin{array}{c}\mathrm{ET} \\
(\mathrm{mm})\end{array}$ & $\begin{array}{c}\mathrm{I}_{40} \\
(\mathrm{~mm})\end{array}$ & $\begin{array}{c}\mathrm{I}_{60} \\
(\mathrm{~mm})\end{array}$ & $\begin{array}{c}\mathrm{I}_{80} \\
(\mathrm{~mm})\end{array}$ & $\begin{array}{c}\mathrm{I}_{100} \\
(\mathrm{~mm})\end{array}$ & $\begin{array}{c}\mathrm{P} \\
(\mathrm{mm})\end{array}$ & $\begin{array}{c}\mathrm{ET} \\
(\mathrm{mm})\end{array}$ \\
\hline 1 & 5.0 & 5.0 & 5.0 & 5.0 & 0 & 47 & 5.0 & 5.0 & 5.0 & 5.0 & & 48 \\
2 & 2.7 & 4.1 & 5.37 & 8 & 0 & 97 & 2.29 & 3.43 & 4.57 & 5.71 & 27.53 & 40 \\
3 & 6.31 & 9.4 & 12.14 & 15.6 & 59.0 & 42 & 3.60 & 5.40 & 7.20 & 9.00 & 1.5 & 68 \\
4 & 7.11 & 10.8 & 14.4 & 18 & 0 & 47 & 8.60 & 12.90 & 17.20 & 21.50 & 16.9 & 43 \\
5 & 8.5 & 12.9 & 17.2 & 21.49 & 0 & 50 & 9.60 & 14.40 & 19.20 & 24.00 & & 42 \\
6 & 11 & 18.2 & 25.71 & 32.14 & 21.6 & 42 & 11.30 & 17.00 & 22.60 & 28.30 & & 44 \\
7 & 12 & 18.0 & 24.02 & 30.02 & 6.8 & 40 & 12.60 & 18.90 & 25.10 & 31.40 & & 72 \\
8 & 11.8 & 17.8 & 23.77 & 29.71 & 0 & 41 & 14.40 & 21.60 & 28.80 & 36.00 & & 42 \\
9 & 12.4 & 19.3 & 25.77 & 32.21 & 0 & 45 & 14.90 & 22.30 & 29.70 & 37.10 & & 40 \\
10 & 15 & 22.6 & 30.85 & 38.57 & 37.6 & 40 & 16.00 & 24.00 & 32.00 & 40.00 & & 40 \\
12 & 15 & 22.3 & 29.71 & 37.14 & 0 & 40 & 16.80 & 25.20 & 33.60 & 42.00 & 39.85 & 40 \\
12 & 15 & 22.3 & 29.71 & 37.14 & 17.9 & 48 & 16.00 & 24.00 & 32.00 & 40.00 & & 40 \\
13 & & & & & & & 16.00 & 24.00 & 32.00 & 40.00 & & 40 \\
\hline Top. & 122 & 183 & 244 & 305 & 142.9 & 579 & 147 & 218 & 289 & 360 & 86 & 599 \\
\hline
\end{tabular}

\subsection{Fruit yield}

Plants flowered about one month after planting and the fruit was harvested five times from 09 August 2017 to 05 October 2017 and from 19 July 2018 to 12 September 2018. In both years, the highest fruit yields were obtained from $\mathrm{I}_{100}$ irrigation treatment with 3681 and $4515 \mathrm{~kg} \mathrm{da}^{-1}$ followed by $\mathrm{I}_{80}\left(3440,4203 \mathrm{~kg} \mathrm{da}^{-1}\right)$ and $\mathrm{I}_{60}$ $\left(3227,3546 \mathrm{~kg} \mathrm{da}^{-1}\right)$ while the lowest yield was 3021 and $2792 \mathrm{~kg} \mathrm{da}^{-1}$ harvested from I 40 irrigation treatment, respectively. In the fertilizer treatments, the highest yields were harvested from DOF with 3462 and $3878 \mathrm{~kg} \mathrm{da}$ ${ }^{1}$, in both seasons respectively followed by CHF with 3307 and $3784 \mathrm{~kg} \mathrm{da}^{-1}$ while the lowest yield was 3258 and $3629 \mathrm{~kg} \mathrm{da}^{-1}$ from OF, respectively as seen in Figure 2.

The effects of irrigation levels on yield were found to be statistically significant $(\mathrm{P}<0.05)$ and the LSD test formed the average yield of 3 groups. In the rank, $\mathrm{I}_{100}$ and $\mathrm{I}_{80}$ were first in group A so $\mathrm{I}_{80}$ irrigation level would be recommended to eggplant producer where water consumption is lower and at the same time they were in the same level of yield, I60 second in group B, and $\mathrm{I}_{40}$ third in group $\mathrm{C}$. It was found to be insignificant $(\mathrm{P}>0.05)$ for 
Ali \& Gençoğlan \& Gençoğlan \&Uçak Yield and Water Use of Eggplants (Solanum melongena L.) Under Different Irrigation Regimes and Fertilizers fertilizer treatment and irrigation $\mathrm{x}$ fertilizer interaction (Table 5). The reason why the eggplant yield varied in experimental years is the difference in the previously cultivated crops and weather conditions.

The results showed that as the amount of irrigation water increased the eggplant yield increased (Figure 1). On the other hand, among the fertilizer treatments, the highest fruit yield of eggplant was harvested from DOF (Figure 2), the reason for this is that DOF fertilizer is developed and activated in a way that makes nutrients more easily available and absorption by the plant (Ibrahim et al., 2010; Tole et al., 2019). These results coincide with that obtained by Aujla et al. (2007) who found that fruit yield of eggplant had a positive response to the increase of nitrogen fertilizer under different irrigation levels. Amiri et al. (2012) concluded that the influence of irrigation on fruit yield was found significant and higher than the influence of $\mathrm{N}$ fertilization and he found among all treatments, irrigation in 6 days interval and application of $120 \mathrm{~kg} \mathrm{~N} \mathrm{ha}^{-1}$ had the highest fruit yield (51.12 ton $\mathrm{ha}^{-1}$ ). Gaveh et al. (2011) demonstrated that total marketable yield in the season increased with increasing irrigation. Kirnak et al. (2001) demonstrated that water stress resulted in a reduction of fresh fruit yield and fruit size of the eggplant. Also, Şenyiğit et al. (2011) reported that the highest yield was obtained from full irrigation treatment and 10\% reduction of full irrigation amount. Gaelen (2012) demonstrated that the highest yield (3154 $\left.\mathrm{kg} \mathrm{da}^{-1}\right)$ was at full irrigation and the lowest yield $\left(1321 \mathrm{~kg} \mathrm{da}^{-1}\right)$ at no irrigation. In other eggplant studies, Karam et al. (2011) reported eggplant yields varying between 13.4 and $33.8 \mathrm{t} \mathrm{ha}^{-1}$ for full and deficit irrigation regimes and Ertek et al. (2006) found that the yield of eggplant fruits ranged between 1010 and $2114 \mathrm{~kg} \mathrm{da}^{-1}$ and Lovelli (2007) reported that eggplant yields varying between $11.4 \mathrm{t} \mathrm{ha}^{-1}$ at kcp: 0.25 and $48.2 \mathrm{t}$ $\mathrm{ha}^{-1}$ at kcp: 0.1. Yenigün and Erdem (2019) found that the yield of eggplant fruits ranged between 2180 and 4760 $\mathrm{kg} \mathrm{da}^{-1}$. As a result, deficit irrigation reduces the yield of eggplant (English, 1990; Pereira et al., 2002; Karam et al., 2006; Fereres and Soriano, 2007).

As a result, deficit irrigation reduces the yield of eggplant (English, 1990; Pereira et al., 2002; Karam et al., 2006; Fereres and Soriano, 2007). All these results are consistent with the results of this research but the changes in yield were due to the difference in irrigation management, soil, eggplant varieties, and climatic conditions. Overall, the result of most studies 'related to eggplant productivity, morphological, and physiological responses under water-conditions limited' showed reductions in fruit yield, quality, and plant vegetative development.

Table 5. Eggplant fruit yield $\left(\mathrm{kg} \mathrm{da}^{-1}\right)$

\begin{tabular}{|c|c|c|c|c|c|c|c|c|c|c|}
\hline \multirow{2}{*}{$\begin{array}{l}\text { Year } \\
\text { Treatment }\end{array}$} & \multicolumn{4}{|c|}{2017} & \multirow[b]{2}{*}{$\begin{array}{l}\text { Average } \\
\text { of fer. }\end{array}$} & \multirow[b]{2}{*}{$\mathrm{I}_{40}$} & \multicolumn{3}{|c|}{2018} & \multirow[b]{2}{*}{$\begin{array}{c}\text { Average } \\
\text { of fer. }\end{array}$} \\
\hline & $\mathrm{I}_{40}$ & $\mathrm{I}_{60}$ & $\mathrm{I}_{80}$ & $\mathrm{I}_{100}$ & & & [60 & $\mathrm{I}_{80}$ & $\mathrm{I}_{100}$ & \\
\hline DOF & 3128 & 3403 & 3604 & 3714 & 3462 & 2928 & 3678 & 4312 & 4593 & 3878 \\
\hline $\mathrm{CHF}$ & 2999 & 3111 & 3424 & 3693 & 3307 & 2727 & 3611 & 4218 & 4579 & 3784 \\
\hline OF & 2937 & 3168 & 3293 & 3635 & 3258 & 2722 & 3340 & 4079 & 4375 & 3629 \\
\hline $\begin{array}{l}\text { Average of } \\
\text { irrigation }\end{array}$ & $3021^{(\mathrm{c})}$ & $3227^{(b c)}$ & $3440^{(a b)}$ & $3681^{(a)}$ & & & & $3546^{(\mathrm{b})}$ & $4203^{(a)}$ & $4515^{(a)}$ \\
\hline LSD (0.05) & & & 267 & & & & & & 33 & \\
\hline
\end{tabular}

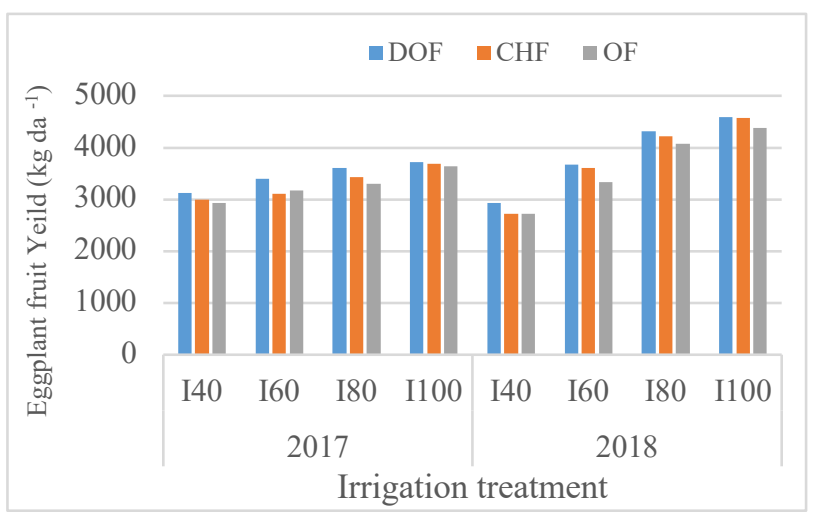

Figure 2. Eggplant fruit yield harvested from irrigation and fertilizer treatment 


\subsection{Water use efficiency (WUE) and irrigation water use efficiency (IWUE)}

WUE and IWUE changed depending on irrigation levels and as the amount of irrigation water increased in general, the WUE and IWUE decreased (Table 6). As it presented in Table 6, in both year, the highest WUE obtained from I 40 as 11.44 and $12.87 \mathrm{~kg} \mathrm{~mm}^{-1}$, respectively and followed by $\mathrm{I}_{60}\left(9.93\right.$ and $\left.12.14 \mathrm{~kg} \mathrm{~mm}^{-1}\right)$ and $\mathrm{I}_{80}$ ( 8.91 and $11.52 \mathrm{~kg} \mathrm{~mm}^{-1}$ ) while the lowest WUE from $\mathrm{I}_{100}$ as 8.23 and $10.36 \mathrm{~kg} \mathrm{~mm}^{-1}$, respectively. The highest IWUE in both seasons obtained from I 40 as $24.76,18.99 \mathrm{~kg} \mathrm{~mm}^{-1}$, respectively, and followed by I60 (17.65 and $\left.16.27 \mathrm{~kg} \mathrm{da}^{-1}\right)$ and $\mathrm{I}_{80}\left(14.10\right.$ and $\left.14.54 \mathrm{~kg} \mathrm{da}^{-1}\right)$ while the lowest IWUE from I 100 as 12.07 and $12.54 \mathrm{~kg} \mathrm{~mm}^{-1}$, respectively.

Even though the highest irrigation water was applied to the $\mathrm{I}_{100}$ treatment, that's IWUE and WUE value was the lowest. On the other hand, in the I 40 treatment applied the lowest irrigation water, the values of IWUE and WUE were higher. Aujla et al. (2007), Lovelli et al. (2007), and Karam et al. (2011) concluded to be the highest WUE value with $11.9 \mathrm{~kg} \mathrm{~mm}^{-1}, 10.3 \mathrm{~kg} \mathrm{~mm}^{-1}$, and $5.6 \mathrm{~kg} \mathrm{~mm}^{-1}$ in the limited irrigation application, respectively. Ayas (2017) found to be maximum both WUE and IWUE values with $9.48 \mathrm{~kg} \mathrm{~mm}^{-1}$ and $13.14 \mathrm{~kg} \mathrm{~mm}^{-1}$ from Kcp4: 0.25 treatments.

The results of this experiment are similar to those given above. Kırnak et al. (2002) found increased WUE values under water stress conditions for eggplant. The higher WUE of plants under stress conditions is because stressed plants wilt far more than unstressed plants and wilting invariably occurs in times when the saturation deficit of the atmosphere is large (Bloch et al., 2006).

Generally, it could also be observed that as the eggplants were exposed to water stress, the water use efficiency of eggplants increased. The lowest amount of water applied ( $\left.\mathrm{I}_{40}\right)$ recorded the highest WUE value, whereas the highest amount of water applied ( $\left.\mathrm{I}_{100}\right)$ resulted in the lowest WUE values in that order. The phenomena whereby water-stressed plants give the higher WUE indicates that as the crops are exposed to water stress there is high dry matter accumulation in the fruit. According to Birhanu and Tilahun (2010), this observation can be attributed to the fact that as total plant biomass decreases with water stress level, fruit dry matter increased, hence there is an increase in water use efficiency when water stress level increases. It was found that the highest WUE and IWUE was in DOF followed by CHF and OF. The reason for higher WUE and IWUE in DOF plot was that DOF increased eggplant yield (Figure 3).

Table 6. Irrigation amount, water requirement water, and irrigation water use efficiency

\begin{tabular}{ccccccccc}
\hline \multicolumn{1}{c}{2017} \\
\hline $\begin{array}{c}\text { Irrigation } \\
\text { treatment }\end{array}$ & $\begin{array}{c}\mathrm{I} \\
(\mathrm{mm})\end{array}$ & $\begin{array}{c}\mathrm{ET} \\
(\mathrm{mm})\end{array}$ & $\begin{array}{c}\text { IWUE } \\
\left(\mathrm{kg} \mathrm{mm}^{-1}\right)\end{array}$ & $\begin{array}{c}\text { WUE } \\
\left(\mathrm{kg} \mathrm{mm}^{-1}\right)\end{array}$ & $\begin{array}{c}\mathrm{I} \\
(\mathrm{mm})\end{array}$ & $\begin{array}{c}\mathrm{ET} \\
(\mathrm{mm})\end{array}$ & $\begin{array}{c}\text { IWUE } \\
\left(\mathrm{kg} \mathrm{mm}^{-1}\right)\end{array}$ & $\begin{array}{c}\text { WUE } \\
\left(\mathrm{kg} \mathrm{mm}^{-1}\right)\end{array}$ \\
\hline $\mathrm{I}_{40}$ & 122 & 264 & 24.76 & 11.44 & 147 & 217 & 18.99 & 12.87 \\
\hline $\mathrm{I}_{60}$ & 183 & 325 & 17.63 & 9.93 & 218 & 292 & 16.27 & 12.14 \\
\hline $\mathrm{I}_{80}$ & 244 & 386 & 14.10 & 8.91 & 289 & 365 & 14.54 & 11.52 \\
\hline $\mathrm{I}_{100}$ & 305 & 447 & 12.07 & 8.23 & 360 & 436 & 12.54 & 10.36 \\
\hline
\end{tabular}

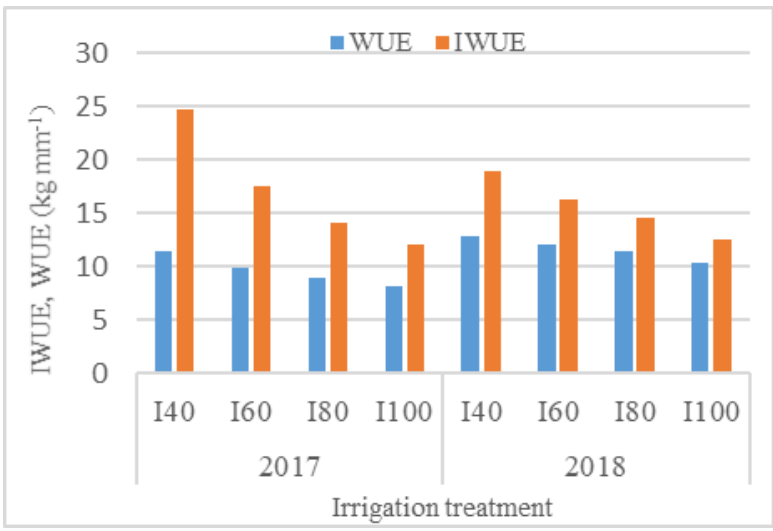

Figure 3 Effect of irrigation level on WUE and IWUE 


\subsection{Plant fresh weight (PFW)}

At the end of the growing season after the last harvest the plant fresh weight was determined, the highest PFW was obtained from $\mathrm{I}_{100}$ irrigation treatment as 4216 and $3906 \mathrm{~kg} \mathrm{da}^{-1}$ in 2017 and 2018 respectively, followed by $I_{80}$ as 4117 and $3788 \mathrm{~kg} \mathrm{da}^{-1}$ then $\mathrm{I}_{60}$ as 3775 and $2953 \mathrm{~kg} \mathrm{da}^{-1}$ while the lowest PFW was obtained in two years with 3118 and $2548 \mathrm{~kg} \mathrm{da}^{-1}$ at $\mathrm{I}_{40}$ irrigation treatment, respectively as it presented in Table 7. For the effect of fertilizer treatment on PFW in every irrigation treatment, the highest was at DOF fertilizer treatment and the lowest was at OF fertilizer treatment as seen in Figure 4.

The effect of irrigation treatments on plant fresh weight values was statistically significant $(\mathrm{P}<0.05)$. According to the LSD test, it was in 3 groups, $\mathrm{I}_{100}$ and $\mathrm{I}_{80}$ in group A, $\mathrm{I}_{60}$ in group $\mathrm{B}$, and $\mathrm{I}_{40}$ in group $\mathrm{C}$ in both seasons. This may be due to the role of water in translocation of photosynthetic assimilates (Inalpulat et al. 2014), thus reflected increases in most of PFW, or due to the depression effect of soil dryness on leaves formation, function, and growth development. It was found to be insignificant for fertilizer treatment and irrigation $\mathrm{x}$ fertilizer interaction ( $\mathrm{P}>0.05)$. Bafeel and Moftah (2008) suggested that the negative effect of drought stress on the yield and its components may be related to the decrease in vegetative growth. Abdrabbo et al. (2017) reported that the highest plant fresh weight was $1399 \mathrm{~g} \mathrm{plant}^{-1}$ at $\mathrm{I}_{100}$ irrigation treatment, also Özbek and Kaman (2017) stated the highest plant fresh weight was $1285.5 \mathrm{~g} / \mathrm{plant}$ at $\mathrm{I}_{100}$ irrigation treatment. The results observed from this research is in agreement with those researches result.

Table 7. Some plant growth and fruit variables result

\begin{tabular}{lcccccccc}
\hline \multicolumn{1}{c}{ Year } & \multicolumn{3}{c}{2017} & \multicolumn{4}{c}{2018} \\
\hline Irrigation treatment & $\mathrm{I}_{100}$ & $\mathrm{I}_{80}$ & $\mathrm{I}_{60}$ & $\mathrm{I}_{40}$ & $\mathrm{I}_{100}$ & $\mathrm{I}_{80}$ & $\mathrm{I}_{60}$ & $\mathrm{I}_{40}$ \\
\hline Plant fresh weight $\left(\mathrm{kg} \mathrm{da}^{-1}\right)$ & $4216^{(\mathrm{a})}$ & $4117^{(\mathrm{a})}$ & $3775^{(\mathrm{b})}$ & $3118^{(\mathrm{c})}$ & $3906^{(\mathrm{a})}$ & $3778^{(\mathrm{a})}$ & $2953^{(\mathrm{b})}$ & $2548^{(\mathrm{c})}$ \\
\hline
\end{tabular}

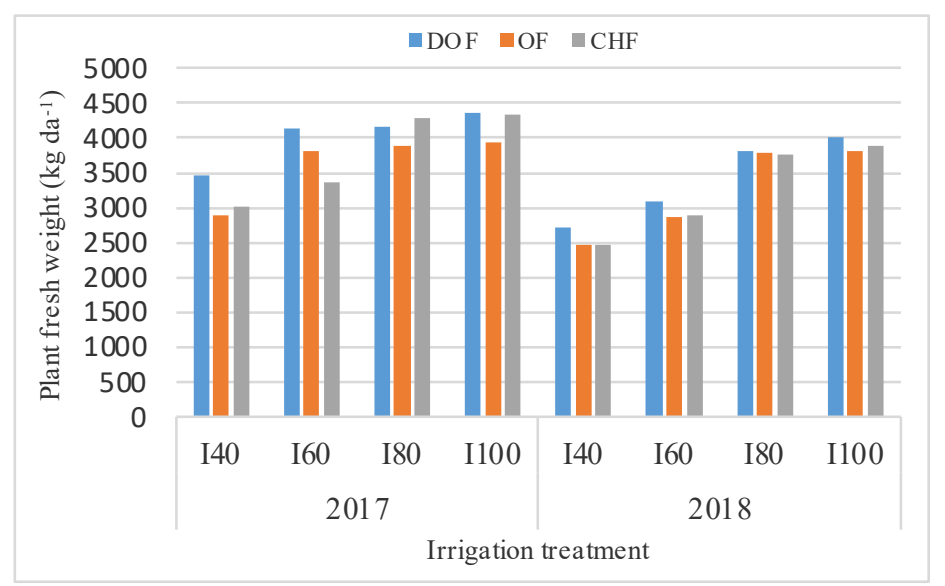

Figure 4. Effect of irrigation level and fertilizers on Plant Fresh weight

\section{Conclusions}

Under Bandırma climatic conditions in 2017-2018 growing years, in four irrigation levels applied by drip irrigation method, and three fertilizers, it was significant differences between the irrigation treatments in yield and plant fresh weight $(\mathrm{P}<0.05)$. But no significant differences were found between $\mathrm{I}_{100}$ and $\mathrm{I}_{80}$ treatments in yield and plant fresh weight in two experiment years. The data obtained from $\mathrm{I}_{100}$ and $\mathrm{I}_{80}$ treatments were taken place in the same group by LSD test and IWUE was higher in $\mathrm{I}_{80}\left(14.54 \mathrm{~kg} \mathrm{~mm}^{-1}\right)$, therefore we can say I80 most suitable irrigation program for eggplant. No significant effect noticed between fertilizers treatments in two experiment years $(\mathrm{P}>0.05)$, nevertheless, it can be said that chemical fertilizer can be replaced by developed organic fertilizer because the highest yield was obtained from DOF fertilizer treatment, at the other side to avoiding the health and environmental damage of chemical fertilizer.

\section{Acknowledgment}

We would like to thank Yeşil Hayat Makine ve Sanayi AŞ. Company for supplying the materials and fertilizers of this research. 


\section{References}

Abdrabbo, M. A. A., Saleh. S. M. and Hashem, F. A., (2017). Eggplant Production under Deficit Irrigation and Polyethylene Mulch. Egypt. J. of Appl. Sci., 32 (7) 148-161.

Allen, R.G., Pereira, L.S., Raes, D., Smith, M., (1998). Crop Evapotranspiration Guidelines for Computing Crop Water Requirements, Irrigation, and Drainage. Paper No: 56, FAO, Rome, p. 300.

Aminifard, M., Aroiee, H., Fatemi, H., Ameri, A., Karimpour, S., (2010). Responses of Eggplant (Solanum melongena L.) to Different Rates of Nitrogen under Field Conditions. Journal of Central European Agriculture. 11 (4) P: 453-458.

Amiri, E., Gohari, A., and Esmailian, Y., (2012). Effect of Irrigation and Nitrogen on Yield, Yield Components, and Water Use Efficiency of Eggplant. African Journal of Biotechnology Vol. 11(13), pp. 3070-3079. Available online at http://www.academicjournals.org/AJB DOI: 10.5897/AJB11.2450 ISSN 1684-5315 (C) 2012 Academic.

Anonymous, (2017). http://www.bandirma.gov.tr/iklim-ve-cografi-konum.

Aujla, MS., Thind, HS., and Buttar, GS., (2007). Fruit Yield and Water Use Efficiency of Eggplant (Solanum Melongema L.) as Influenced by Different Quantities of Nitrogen and Water Applied Through Drip and Furrow Irrigation. Scientia Horticulturae 112 (2007) $142-148$.

Ayas, S., (2017). The Effects of Irrigation Regimes on the Yield and Water Use of Eggplant (Solanum melongena L.) Toprak Su Dergisi, 6 (2): $49-58$.

Bafeel, SO., Moftah, AE., (2008). Physiological Response of Eggplants Grown under Different Irrigation Regimes to Anti transplant treatments. Saudi J. Biol. Sci. 15(2): 259-267.

Birhanu, K., and Tilahun, K., (2010). Fruit Yield and Quality of Drip-Irrigated Tomato under Deficit Irrigation. African Journal of Food, Agriculture, Nutrition, and Development; 10(2), 2139-2157.

Bloch, D., Hoffmann, C.M., Marlander, B., (2006). Impact of Water Supply On Photosynthesis, Water Use, and Carbon Isotope Discrimination of Sugar beet genotypes. Eur. J. Agron. 24, 218-225.

Chaves, M.M., Maroco, J.P., Pereira, J.S., (2003). Understanding Plant Responses Todrought From Genes to Whole Plant. Funct. Plant Biol. $30,23-264$.

Çolak, Y.B., Yazar, A., Çolak, İ., Akça, H., Duraktekin, G., (2017). Evaluation of Crop Water Stress Index (CWSI) for Eggplant Undervarying Irrigation Regimes Using Surface and Subsurface Drip Systems. Agriculture and Agricultural Science Procedia 4(1), 372 -382 .

De, C., Jun Jie, H. and Kui C., (1996). Studies on Fertilizer Application Levels of Seedling Stage of Eggplant Raised with Mixed Media. China Vegetables, 4: 16-18.

Demirel, K., Genc, L., Bahar, E., Inalpulat, M., Smith, S., \& Kizil, U., (2014). Yield Estimate Using Spectral Indices in Eggplant and Bell Pepper Grown Under Deficit Irrigation. Fresenius Environ. Bull, 23, 1232-1237.

Demirel, K., Genç, L., Saçan, M. (2012). Yarı Kurak Koşullarda Farklı Sulama Düzeylerinin Salçalık Biberde (Capsicum Annum Cv. Kapija) Verim ve Kalite Parametreleri Üzerine Etkisi. Tekirdağ Ziraat Fakültesi Dergisi, 9(2):7-15

DePascale, S., R. Tamburrino, A. Maggio, G. Barbieri, B. Fogliano, and R. Pernice., (2006). Effect of Nitrogen Fertilization on the Nutritional Value of Organically and Conventionally Grown Tomatoes. Acta Hortic. 700: 107-110.

Diaz-Perez, J., (2015). Eggplant (Solanum melongena L.) Plant Growth and Fruit Yield as Affected by Drip Irrigation Rate. HORTSCIENCE 50(11):1709-1714.

Dinh Hoa Vu., (2008). Effect of Organic Fertilizer on Fruit Yield and Quality of Eggplant (Solanum melongena L.). In AGRIS since, 13(3):137-142

Doorenbos, J., Pruitt, W.O., (1977). Guidelines for Predict of Water Requirement. Irrigation and Drainage No. 24, FAO, Rome, p. 144.

El-Miniawy, S., (2015). Growth and Yield of Eggplant Grown under Drought Stress Conditions and Different Potassium Fertilizer Rates. Middle East Journal of Agriculture Research ISSN 2077-4605 Volume: 04 | Issue: 04 | Oct.-Dec. P:1113-1124.

English, M.J., (1990). Deficit Irrigation: Analytical Framework. J. Irrig. Drain. Eng. 116(1), 399-412

Ertek, A., Kanber, R., (2003). Effects of Different Drip Irrigation Programs on the Boll Number and Shedding Percentage and Yield of Cotton. Agric. Water Manage. 60, 1-11.

Ertek, A., Sensoy, S., Kucukyumuk, C., Gedik, I., (2006). Determination of Plant-pan Coefficients for Field-Grown Eggplant (Solanum melongena L.) Using Class, A pan Evaporation values. Agric.Water Manage., (85): 58-66.

Fereres, E., Soriano, M. A., (2007). Deficit Irrigation for Reducing Agricultural Water Use. Journal of Experimental Botany. 58(2), $147-159$.

Gaelen, H., (2012). Validation of The Aqua Crop Model for Irrigated African Eggplant (Solanum macrocarpon) at the Unza Field Station. The University of Zambia Lusaka: 99(1).

Garrity, P.D., Watts, D.G., Sullivan, C.Y., Gilley, J.R., (1982). Moisture Deficits and Grain Sorghum Performance: Evapotranspiration-yield Relationships. Agron. J. 74, 815-820. 
Ali \& Gençoğlan \& Gençoğlan \&Uçak Yield and Water Use of Eggplants (Solanum melongena L.) Under Different Irrigation Regimes and Fertilizers Gaveh, E. A., Timpo, G. M., Agodzo, S. K., and Shin, D. H., (2011). Effect of Irrigation, Transplant Age, and Season on Growth, Yield, and Irrigation Water Use Efficiency of the African Eggplant. Hort. Environ. Biotechnol. 52(1):13-28.

Gençoğlan, C., Altunbey, H., Gençoğlan, S., (2006). Response of Green Bean (P. Vulgaris L.) to Subsurface Drip İrrigation and Partial Root Zone-Drying Irrigation. Agricultural Water Management, 84(3): 274-280.

Hochmuth, G.J., R.C. Hochmuth, M.E. Donley and E.A. Hanlon, (1993), Eggplant yield in response to potassium fertilization in sandy soil. Hort. Science, 28(10): 1002-1005.

Howell, T.A., Cuence, R.H., Solomon, K.H., (1990). Crop Yield Response. In: Hoffman, G.J., et al. (Eds.), Management of Farm Irrigation Systems. ASAE, St. Joseph, MI, p. 312.

Ibrahim S. S., El-Midany A. A., Boulos T. R., (2010). Effect of Intensive Mechanical Stresses on Phosphate Chemistry as A Way to Increase Its Solubility for Fertilizer Application. Physicochem. Probl. Miner. Process. 44- 79-92.

Inalpulat, M., Genc, L., Kizil, U. and Aksu, S., (2014). Responses of Eggplant to Pruning Under Irrigation Deficiency. Int. Conf. on Biological, Civil, and Environmental Engineering March 17-18, Dubai, UAE.

James, D.W. Hanks, R. J., Jurinak, J.J., (1982). Modern Irrigation Soils. John Wiley and Sons. New York, pp 235.

Karam F., Sabiha R., Skaf S., Breidy J., RouphaelY. And Balendonck J., (2011). Yield and Water Use of Eggplants (Solanum Melongena L.) Under Full and Deficit Irrigation Regimes. Agricultural Water Management 98: 1307-1316.

Karam, F., Lahoud, R., Masaad, R., Daccache, A., Mounzer, O., Rouphael, Y., (2006). Water Use and Lint Yield Response of Drip Irrigated Cotton to the Length of Irrigation Season. Agric. Water Manage. 85(3), 287-295.

Kirnak, H., Kaya, C., Tas, I., Higgs, D., (2001).The Influence of Water Deficit on Vegetative Growth, Physiology, Fruit Yield, and Quality in Eggplants. Bulgarian, J. Plant Physiol. 27(3-4): 34-46.

Kirnak, H., Tas,, 'I., Kaya, C., Higgs, D., (2002). Effects of Deficit Irrigation on Growth, Yield and Fruit Quality of Eggplant under SemiArid Conditions. Aust. J. Agric. Res. 53, 1367-1373.

Kirda C., (2002). Deficit Irrigation Scheduling Based on Plant Growth Stages Showing Water Stress Tolerance. Deficit Irrigation Practice. Water Rep. Rome FAO, 22: 3-10.

Louisa MA, Taguiling G., (2016). Response of Some Vegetable Plants to Green Biomass Enriched Compost. IOSR Journal of Agriculture and Veterinary Science (IOSRJAVS). 9(5):67-74 [e-ISSN: 2319-2380] [p-ISSN: 2319-2372] Available: www.iosrjournals.org.

Lovelli, S., Perniola, M., Ferrara, A., Tommaso, T., (2007). Yield response factor to water (ky) and water use efficiency of Carthamus Tinctorius L. And Solanum melongena L. Agricultural Water Management, (92):73-80.

Mohawesh, O. and Karajeh, M., (2014). Effects of Deficit Irrigation on Tomato and Eggplant and Their Infection with the Root-Knot Nematode under Controlled Environmental Conditions. Archives of Agronomy and Soil Science, 2014 Vol. 60, No. 8: 1091-1101.

Morris, M., Kelly, VA., Kopicki, RJ. and Byerlee, D., (2007). Fertilizer use in African Agriculture: Lessons learned and good practice guidelines. Washington, DC: The World Bank. The Rain Forest Area of Nigeria. Applied Tropical Agriculture. 5:20-23.

Naderi, R., Bijanzadeh, E., (2014). Organic amendments and nitrogen effects on growth and chemical composition of two cultivars of safflower (Carthamus tinctorius L.) Australian Journal of Crop Science. 8(4):577-581.

Özbek, Ö. and Kaman, H., (2017). Yarı ıslatmalı sulamayla patlıcan yetiştiriciliği. Akademik Ziraat Dergisi Cilt:6 Özel Sayı:289-296.

Pereira, L.S., Oweis, T., Zairi, A., (2002). Irrigation Management under Water Scarcity. Agric. Water Manage. 57, $175-206$.

Rosati A, Badeck FW, Dejong TM (2001). Estimating Canopy Light Interception and Absorption Using Leaf Mass Per Unit Leaf Area in Solanum melongena. Ann. Bot. 88: 101-109.

Steel, R.G.D., Torrie, J.H., (1980). Principles and Procedures of Statistics, second ed. McGraw-Hill, New York.

Şenyiğit, U., Kadayifci, A., Ozdemir, F. O., OZ, H., and Atilgan, A.,(2011). Effects of Different Irrigation Programs on Yield and Quality Parameters of Eggplant (Solanum melongena L.) Under Greenhouse Conditions Department of Agricultural Structure and Irrigation, Faculty of Agriculture, Suleyman Demirel University. No: 32260, Isparta.

Tanner, C.B., Sinclair, T.R., (1983). Efficient Water Use in Crop Production: research or re-search? In: Taylor, H.M., et al. (Eds.), Limitations to Efficient Water Use in Crop Production. ASA, Madison, WI, pp. 1-27.

Tole, I., Habermehl-Cwirzen, K. and Cwirzen, A., (2019). Mechanochemical Activation of Natural Clay Minerals: An Alternative to Produce Sustainable Cementitious Binders. Mineralogy and Petrology. 113: 449-462.

Ünlükara, A., Kurunc, A., Kesmez, G., Yurtseven, E., AND Suarez, D., (2010) Effects of Salinity on Eggplant (Solanum Melongena L.) Growth and Evapotranspiration. Irrig. and Drain. 59: 203-214.

Yenigün, S.D., Erdem, T., (2019). Determination of Water Use Characteristics of Eggplant in Tekirdağ Conditions. Tekirdă̆ Ziraat Fakültesi Dergisi.16(2): 19-30

Yıldırım, M., (2015). Water and Radiation Use Efficiency of Eggplant Under None Water Stress Condition in Semi-Arid Region. ÇOMÜ Zir. Fak. Derg. (COMU J. Agric. Fac.) 3 (2): 71-77. 